Available online at GSC Online Press Directory

GSC Biological and Pharmaceutical Sciences

e-ISSN: 2581-3250, CODEN (USA): GBPSC2

Journal homepage: https://www.gsconlinepress.com/journals/gscbps

(RESEARCH ARTICLE)

\title{
Microalgal structure and diversity in some canals near garbage dumps of Bobongo basin in the city of Douala, Cameroun
}

\author{
Ndjouondo Gildas Parfait 1, ${ }^{*}$, Mekoulou Ndongo Jerson ${ }^{2}$, Kojom Loïc Pradel ${ }^{3}$, Taffouo Victor Désiré 4 , \\ Dibong Siegfried Didier ${ }^{5}$ \\ ${ }^{1}$ Department of Biology, High Teacher Training College, The University of Bamenda, P.O. BOX 39 Bambili, Cameroon \\ ${ }^{2}$ Department of Animal organisms, Faculty of Science, The University of Douala, PO.BOX 24157 Douala, Cameroon. \\ ${ }^{3}$ Department of Animal organisms, Faculty of Science, The University of Douala, PO.BOX 24157 Douala, Cameroon. \\ ${ }^{4}$ Department of Botany, Faculty of Science, The University of Douala, PO.BOX 24157 Douala, Cameroon. \\ ${ }^{5}$ Department of Botany, Faculty of Science, The University of Douala, PO.BOX 24157 Douala, Cameroon.
}

Publication history: Received on 14 January 2020; revised on 06 February 2020; accepted on 10 February 2020

Article DOI: https://doi.org/10.30574/gscbps.2020.10.2.0013

\begin{abstract}
Anarchical and galloping anthropization is increasingly degrading the wetlands. This study aimed at determining the structure, diversity and spatiotemporal variation of microalgae from a few canals in the vicinity of garbage dumps of the Bobongo basin to propose methods of ecological management of these risk areas. Sampling took place from March 2016 to April 2019. Pelagic algae as well as those attached to stones and macrophytes were sampled in 25 stations. These algae samples were brought back to laboratory for identification and counting. The specific richness amounts to 13 classes, 34 orders, 52 families, 69 genera and 116 species. The dominant class is that of Bacillariophyceae (33 species) with a proportion of $28.45 \%$. Results based on correspondence factor analysis revealed 3 groups of stations (clusters): the group I from stations 16, 21 and 25 consisted of exclusive species such as Cyclotella ocellata, Cymbella gamma, Gomphosphaeria natans, Navicula cryptocephalla and Tabellaria flocculosa. Group II from stations 18, 22, 23 and 24 consisted of exclusive species such as Aphanizomenon flosaquae, Aphanocapsa holsatica, Astasia limpida and Ulothrix zonata. Group III was made up of species common to all stations. Cyclotella ocellata, Cymbella gamma, Gomphosphaerium natans, Navicula cryptocephalla and Tabellaria flocculosa are hydrocarbon-polluting species. Our analysis is, to our knowledge, the first demonstrate the use of microalgal species as indicators of pollution in the context of environmental management for better monitoring of the quality of watercourses. In addition, these species can be used as bio-purifiers of polluted water in hydrocarbon.
\end{abstract}

Keywords: Bobongo basin; Microalgal diversity; Pollution; Channel

\section{Introduction}

Wetlands are areas where water is the main determinant of the environment, and associated plant and animal life [1]. These wetlands are one of the most productive environments worldwide. They are the cradle of biological diversity and provide water and primary productivity from which countless species of plants and animals depend for their survival [2, 3]. Douala, economic capital of Cameroon, has a vast hydrographic network with important lowland swamps, most of which is influenced by anarchic anthropization [4].

Indeed, Cameroon experiences difficulties to implement its urbanization policies for many years. A body of events including 1980-1990 and 2007 global economic crisis, devaluation of the currency and following restrictive policies have been pointed with the finger. As a consequence, precarious and unhealthy neighborhoods such as "Cite-berge",

\footnotetext{
${ }^{*}$ Corresponding author

E-mail address: parfaitgildas@yahoo.fr
} 
"Bobongo" and "Ndogpassi IIIa" have proliferated in Douala [5]. This economic constraint has led people to settle in areas classified as non-constructive (lowland swamp) hence the conjunction of certain anthropization-related factors that exacerbate the vulnerability of exposed populations. A concrete example concerns the management of household waste in different neighborhoods [6]. It is well known that the waste management is one of the most worrying socioenvironmental issues in the city of Douala [7].

Although the garbage collection national company does not fully cover the sectors because of insufficient collection trucks and certain hard-to-reach sectors, populations close to drains and canals take advantage of this to dump their garbage [8]. These current waters contain a large amount of pigsties, cesspools and anarchic landfills [5, 6]. The proliferation of precarious and unhealthy neighborhoods in these lowlands results from laxity of heads of blocs and neighborhoods as well as public authorities [9].

Micro-algae are organisms that react directly to sudden changes in the environment related to pollution and their presence depends on the degree of pollution [10]. Some species can disappear and others resist as a result of pollution and its level. Some authors showed that resistant species or groups of species can find satisfactory conditions even though the pollution of their environment. These can grow abundantly by inhibiting growth of others sympatric species [11].

The understanding of structure and functioning of these micro-algae would be helpful in fight against pollution of hydrosystems through their potential of remediation. Management studies of risk areas have been carried out by urban planners for long. These concerned spatial risk analyzes, exposures and vulnerabilities to floods. Very few studies addressed structure and functioning of photosynthetic micro-organisms in a given hydrosystem [11, 12, 13]. This study therefore aimed at determining the structure and, the spatial and temporal variation of micro-algae of some canals near the garbage dumps of the Bobongo basin to propose methods of ecological management of these risk areas.

\section{Material and methods}

\subsection{Presentation of study area}

Douala is subdivided into 11 sub-watersheds [4]. The study area is part of the northern equatorial climate zone. The average annual temperature is $26.4{ }^{\circ} \mathrm{C}$. Precipitation shows that Douala is rainy with rainfall extending over 9 months with an average ranging from $800 \mathrm{~mm}$ (August) to $300 \mathrm{~mm}$ (February). The average annual humidity, evaporation and isolation is $78.3 \%, 50.6 \%$ and $109.6 \%$ respectively. The prevailing wind carries the monsoon [4]. The study took place in the Bobongo sub-watershed, which includes: Cite-Berge, Bobongo and Ndogpassi IIIa neighborhoods (Fig. 1). The main anthropogenic activities in the study area include pigs and sheep farming, automobile mechanics and trades. Waste from these activities as well as households are directly dumped in canals that drain them to the rivers. There are specific canal disposal points that lead to physical pollution (plastics bottles and papers) and organic pollution (pigs manures and chickens droppings).

Sampling took place from March 2016 to April 2019. The study was conducted in 25 waste disposal points (stations) (Table 1). These points located in canals have been chosen according to the extent of the pollution which directly offers a particular aspect to the hydrosystem.

\subsection{Sampling}

\subsubsection{Qualitative sampling of micro-algae}

The qualitative aspect of phytoplankton was determined from samples contained in $5 \mathrm{~L}$ buckets and filtered using a plankton net (200 L of water filtered in total). After harvesting, samples were immediately fixed by addition of formaldehyde $5 \%$. The solid substrate, like submerged vegetation in the stream was sampled. These plants were pressed and scraped for larger diameter species. The contents were rinsed in a container with distilled water. Sample was shaken and filtered through a sieve to remove remains of macrophytes, small pebbles, leaves or other large particles. The content was fixed with formaldehyde $5 \%$ again.

\subsubsection{Quantitative sampling of micro-algae}

The quantitative sampling of phytoplankton was done by filtration after collection of $100 \mathrm{~L}$ water using a $5 \mathrm{~L}$ bucket. A jar was used for collecting periphyton which was thereafter pressed and scraped on a surface of $(30 \times 30) \mathrm{cm}^{2}$. This 
was diluted with distilled water up to $60 \mathrm{~mL}$ and then fixed with formaldehyde 5\%. Each jar has been labeled and samples were introduced into a cooler for dark storage.

\subsection{Laboratory procedures}

\subsubsection{Qualitative Analysis of micro-algae}

Sub-samples of $10 \mathrm{~mL}$ were done using beakers for performing qualitative analysis of micro-algae. Micro-algae specimens were allowed for sedimentation at the bottom of beakers for $24 \mathrm{~h}$. Thereafter, a drop of each sample was mounted slide and cover slide for microscopic examination (OLYMPUS) under right light. Two preparations were made for each sample. Identification were carried out directly under the light microscope (OLYMPUS) using identification keys described elsewhere [15, 16, 17, 18, 19, 20, 21]. To be noted, drawings and photographs were made for hard-to-identify individuals for more details about their measurements.

\subsubsection{Quantitative Analysis of micro-algae}

After depositing sampled jars, homogenization was performed. Sub-samples of $10 \mathrm{~mL}$ per beaker were made. After stirring each beaker left at rest and under the lee of light for 24 hours, $1 \mathrm{~mL}$ of contents was taken using a micropipette and then poured into counting plates of Malassez. An OLYMPUS photonic microscope was used for counting individuals. At least 200 individuals were counted. The counting unit of the filaments was set at $100 \mu \mathrm{m}$ as 1 individual. Colonies and coenobes were considered as 1 individual [22].

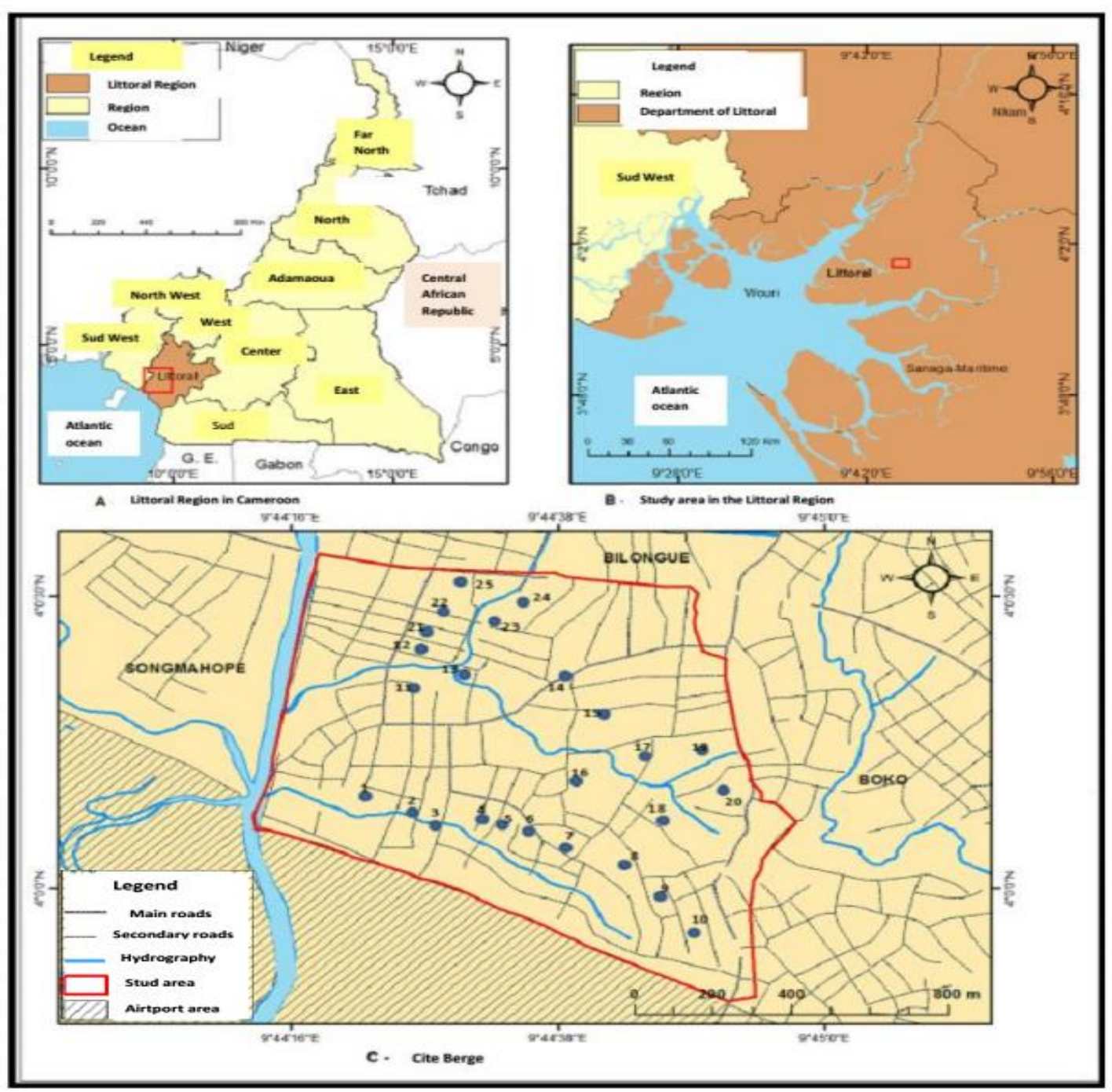

Figure 1 Location of the study area (Mapping Institute modified by Ndjouondo [14] 
Table 1 Geolocation of study stations

\begin{tabular}{|c|c|c|c|c|}
\hline Stations & Longitude (x) & Latitude (y) & $\begin{array}{l}\text { Denomination of } \\
\text { points }\end{array}$ & Type of waste \\
\hline 1 & 582505 & 442642 & Two iron bridges & Household waste and plastics bottles \\
\hline 2 & 582240 & 442807 & Saint-Angel & plastics bottles, Household waste \\
\hline 3 & 582282 & 442818 & Laugh & Household waste and plastics bottles \\
\hline 4 & 582329 & 442806 & Bangoua bridge & Household waste and plastics bottles \\
\hline 5 & 582399 & 442751 & No respect & Pig manure and plastics bottles \\
\hline 6 & 582480 & 442646 & Entry to know & Household waste and plastics bottles \\
\hline 7 & 582880 & 442519 & White house & Household waste and plastics bottles \\
\hline 8 & 582442 & 442942 & Bayanguam bridge & Plastics bottles, Household waste \\
\hline 9 & 582087 & 442890 & One maouth & Pig manure \\
\hline 10 & 581952 & 442778 & Third bridge & Plastics bottles and household waste \\
\hline 11 & 582010 & 442794 & Libanese bridge & Household waste and plastics bottles \\
\hline 12 & 581876 & 442647 & Pigstry bridge & Household waste \\
\hline 13 & 582108 & 442426 & Bridge little Paris & $\begin{array}{l}\text { Plastics bottles, household waste and } \\
\text { Pig manure }\end{array}$ \\
\hline 14 & 582241 & 442366 & $\begin{array}{l}\text { Bridge } \quad \text { thousand } \\
\text { problems }\end{array}$ & Household waste and plastics bottles \\
\hline 15 & 582517 & 442186 & Small market bridge & Household waste and plastics bottles \\
\hline 16 & 582462 & 442210 & Cemetery bridge & Household waste \\
\hline 17 & 581900 & 442468 & Bridge block 6 & Household waste and plastics bottles \\
\hline 18 & 581987 & 442826 & Second bridge & Household waste and Pig manure \\
\hline 19 & 582400 & 443010 & Carrefour Mauritius & Household waste and Pig manure \\
\hline 20 & 581953 & 443095 & Bridge block 7 & Household waste and Pig manure \\
\hline 21 & 582407 & 443054 & Under mango & Household waste and Pig manure \\
\hline 22 & 582121 & 442341 & Stunt bridge & $\begin{array}{l}\text { Household waste, chicken droppings } \\
\text { and Pig manure }\end{array}$ \\
\hline 23 & 582606 & 442623 & Bangou's home & $\begin{array}{l}\text { Household waste, chicken droppings } \\
\text { and Pig manure }\end{array}$ \\
\hline 24 & 582610 & 442588 & Behind Shell & $\begin{array}{l}\text { Household waste, chicken droppings } \\
\text { and Pig manure }\end{array}$ \\
\hline 25 & 582666 & 442645 & $\begin{array}{l}\text { Bridge } \\
\text { entrance }\end{array}$ & Pig manure and chicken droppings \\
\hline
\end{tabular}

\subsection{Determination of ecological parameters}

\subsubsection{Specific richness}

The specific richness (S) is defined by the total number of taxa identified in a sample. It is an element that indicates the specific variety of the stand in other words its species richness. Species richness may well be a distinctive criterion of the ecosystems or stations studied within a given ecosystem. 


\subsubsection{Diversity indices}

A body of diversity indices were computed namely Shannon-Weaver index, equilibrium of Pielou, dominance index, heterozygosity, Simpson's index and Hill index [14]. The Shannon-Weaver (H') index represents a wealth of information on the stand structure of a given sample and how individuals are distributed among different species. A low diversity index indicates that the community is young with high multiplication rate with dominance of one or a few species, while a high index characterizes mature populations with a complex specific composition with a stability relatively large population. The Shannon diversity index ( $\mathrm{H}$ ') for a sample corresponds to the value calculated from the formula: $\mathrm{H}^{\prime}=-\sum_{i=1}^{S}((\mathrm{ni} / \mathrm{N}) \times \log 2(\mathrm{ni} / \mathrm{N}))$, with $\mathrm{ni}=$ number of individuals belonging to a species, $\mathrm{N}=$ total number of species. The regularity of Pielou (J) is given by the formula: $\mathrm{J}=\mathrm{H}^{\prime} / \log _{2} \mathrm{~S}$, with $\mathrm{S}=$ total volume. The dominance index "d" of Berger and Parker which has the formula $d=N \max / \mathrm{N}$. Nmax is the maximum abundance or number of the most common individuals in the medium and $\mathrm{N}$ is the total abundance. It establishes the dominance of the species and shows that, if $d$ is weak, that is to say, it tends to 0 , the diversity is great and the dominance is zero. When $\mathrm{d}$ tends to 1 , one or a few species are dominant and a low diversity. Simpson's D index is D $=\mathrm{WNi}(\mathrm{Ni}-1) / \mathrm{N}(\mathrm{N}-1)$ or $\mathrm{D}=\mathrm{WPi} 2$. This index represents the probability that two individuals selected at random from a sample belong to the same species. To know the number of dominant species, the Hill index is calculated $=(1 / \mathrm{D}) / \mathrm{expH}$ '.

\subsubsection{Density of micro-algae}

Density (D) of micro-algae was computed using the following formula [22]: $\mathrm{D}=\mathrm{Ni} \times 1000 \times \mathrm{V} / \mathrm{V}$, where $\mathrm{D}$ is the number of individuals per liter (ind/L), $\mathrm{Ni}=$ number of individuals for a given species, $\mathrm{V}=$ volume of the sample and $\mathrm{v}=$ volume of the subsample counted in $\mathrm{mL}$.

\subsection{Statistical analysis}

Microsoft Office Excel 2010 was used for keying and coding data collected during the study. Qualitative and quantitative variables were presented as frequency and mean \pm standard deviations respectively in charts. Correspondence Factor Analysis (CFA) was applied to stand composition to group sampling sites according to their floristic similarities. These analyses were performed using XLSTAT software version 11.0.0.28844 and Past version 3.02a for the dendrograms.

\section{Results}

\subsection{Specific wealth of the study area}

The specific richness of environment amounts to 13 classes, 34 orders, 52 families, 69 genera and 116 species. The dominant class is that of Bacillariophyceae (33 species) with a proportion of $28.45 \%$ (Table 2). The least important classes are those of Pyramimonadaphyceae, Trebouxiophyceae and Ulophyceae with 1 species each (00.86\%). The specific richness varied between the studies stations (Fig. 2). The highest values were reported at stations 7 and 17 with 26 species while the lowest values were recorded at stations 2 and 9 with 12 species. Besides, Diatoms were present at all stations whith a maximum of 19 species at station 7. They are followed by Cyanophyceae and Chlorophyceae classes.

Table 2 Specific richness of the study area.

\begin{tabular}{|c|c|c|c|c|}
\hline Classes (Proportions) & Orders & Families & Genera & Species \\
\hline \multirow[t]{11}{*}{ Bacillariophyceae (28.448\%) } & Bacillariales & Bacillariophyceae & 1 & 2 \\
\hline & Cocconeidales & Achnanthidiaceae & 1 & 1 \\
\hline & Cymbellales & Cymbellaceae & 1 & 5 \\
\hline & & Gomphonemataceae & 1 & 1 \\
\hline & Fragilariales & Fragilariaceae & 2 & 3 \\
\hline & & Staurosiraceae & 1 & 1 \\
\hline & Naviculales & Naviculaceae & 1 & 1 \\
\hline & & Diploneidaceae & 1 & 1 \\
\hline & & Naviculaceae & 1 & 6 \\
\hline & & Pinnulariaceae & 2 & 4 \\
\hline & Rhopalodiales & Rhopalodiaceae & 1 & 1 \\
\hline
\end{tabular}


Chlorophyceae $(09.482 \%)$

Conjugatophyceae

$(09.482 \%)$

Coscinodiscophyceae $(02.586 \%)$

Cryptophyceae (02.586\%)

Cyanophyceae $(20.689 \%)$

Dinophyceae (04.310\%)

Euglenophyceae (06.896\%)

Mediophyceae (07.758\%)

Peranemea (01.724\%)

Pyramimonadophyceae $(00.862 \%)$

Trebouxiophyceae $(00.862 \%)$

Ulophyceae (00.862\%)
Surirellales

Tabellariales

Chaetophorales

Chlamydomonales

oedogoniales

Sphaeropleales

Desmidiales

Zygnematales

Aulacoseirales

Coscinodiscales

Melosirales

Cryptomonadales

Pyrenomonadales

Chroococcales

Nostocales

Oscillatoriales

Spirulinales

Synechococcales

Gloeodiniales

Gymnodiniales

Peridiniales

Euglenales

Stephanodiscales

Thalassiosirales

Natomonadida

Pyramimonadales

Chlorellales

Ulothricales
Surirellaceae 1

Tabellariaceae

Chaetophoraceae

Uronemataceae

Chlamydomonaceae

oedogoniaceae

Selenastraceae

Radiococcaceae

Hydrodictyaceae

Closteriaceae

Desmidiaceae

Gonatozygaceae

Zygnemataceae

Aulacoseiraceae

Coscinodiscaceae

Melosiraceae

Cryptomonadaceae

Pyrenomonadaceae

Gomphosphariaceae

Aphanizomenonaceae

Nostocaceae

Rivulariaceae

Oscillatoriaceae

Microcoleaceae

Oscillatoriaceae

Spirulinaceae

Merismopediaceae

Gloeodiniaceae

Gyrodiniaceae

Peridiniaceae

Euglenoideae

Phacaceae

Euglenaceae

Stephanodiscaceae

Skeletonemataceae

Thalassiosiraceae

Astasiidae

Pyramimonadaceae

Chlorellaceae

Ulothricaceae
1

6

2

1

2

2

2

1

1

2

5

1

3

3

3

1

2

1




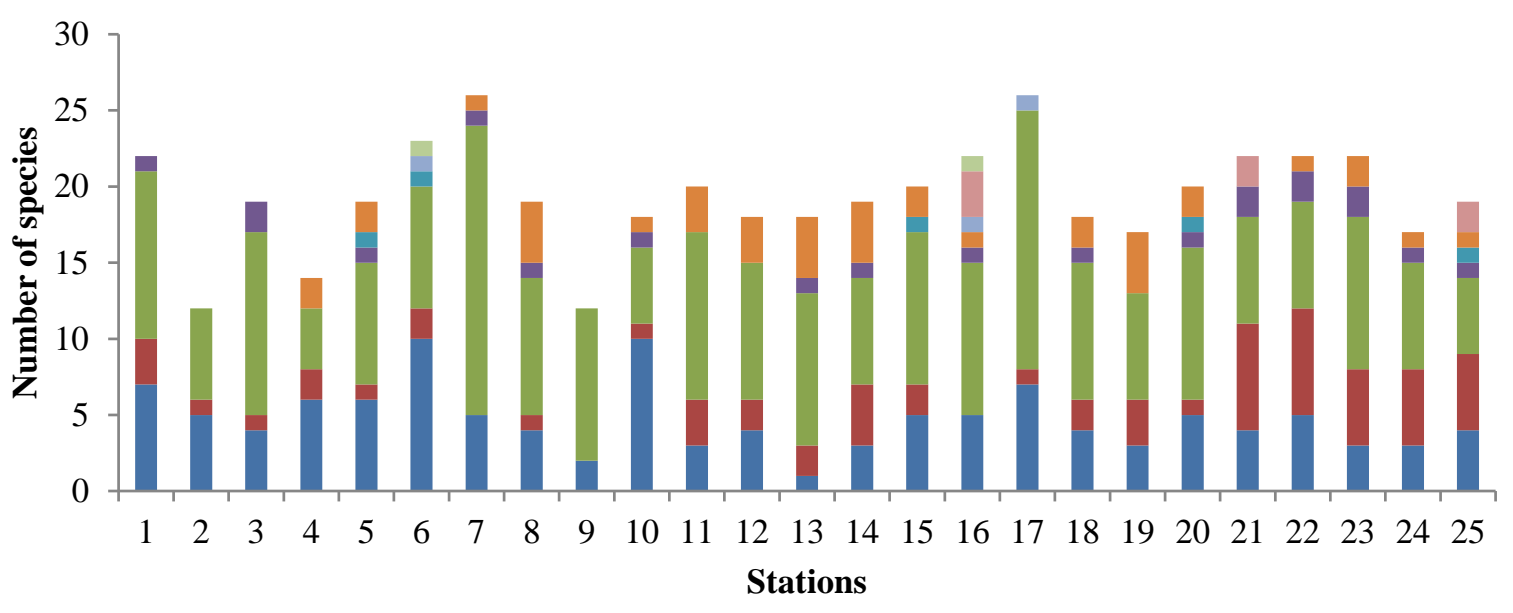

Cyanophyceae $\square$ Chlorophyceae $\square$ Diatomophyceae $\square$ Zygophyceae $\square$ Cryptophyceae
$\square$ Euglenophyceae $\square$ Chrysophyceae $\square$ Dinophyceae $\square$ Prasinophyceae

Figure 2 Specific richness of the different classes of microalgae with regard to the study stations.

\subsection{Diversity indices of study stations}

The diversity indices of the different study stations vary in a "sawtooth" way (Fig. 3). However, the highest values appear mainly between stations 21 and 25. The dominance index of Simpson is close to 0 and varies from 0.05 (station 21) to 0.17 (station 2). The Shannon-Weaver diversity index is low and ranges from 2.08 (station 2 ) to 2.97 (station 21). The Hill index varies from 0.57 (station 7) to 0.91 (station 24). The regularity of Pielou varies from 0.81 (station 1) to 0.97 (station 24). The dominance of Berger-Parker varies from 0.08 (station 24) to 0.35 (station 2).

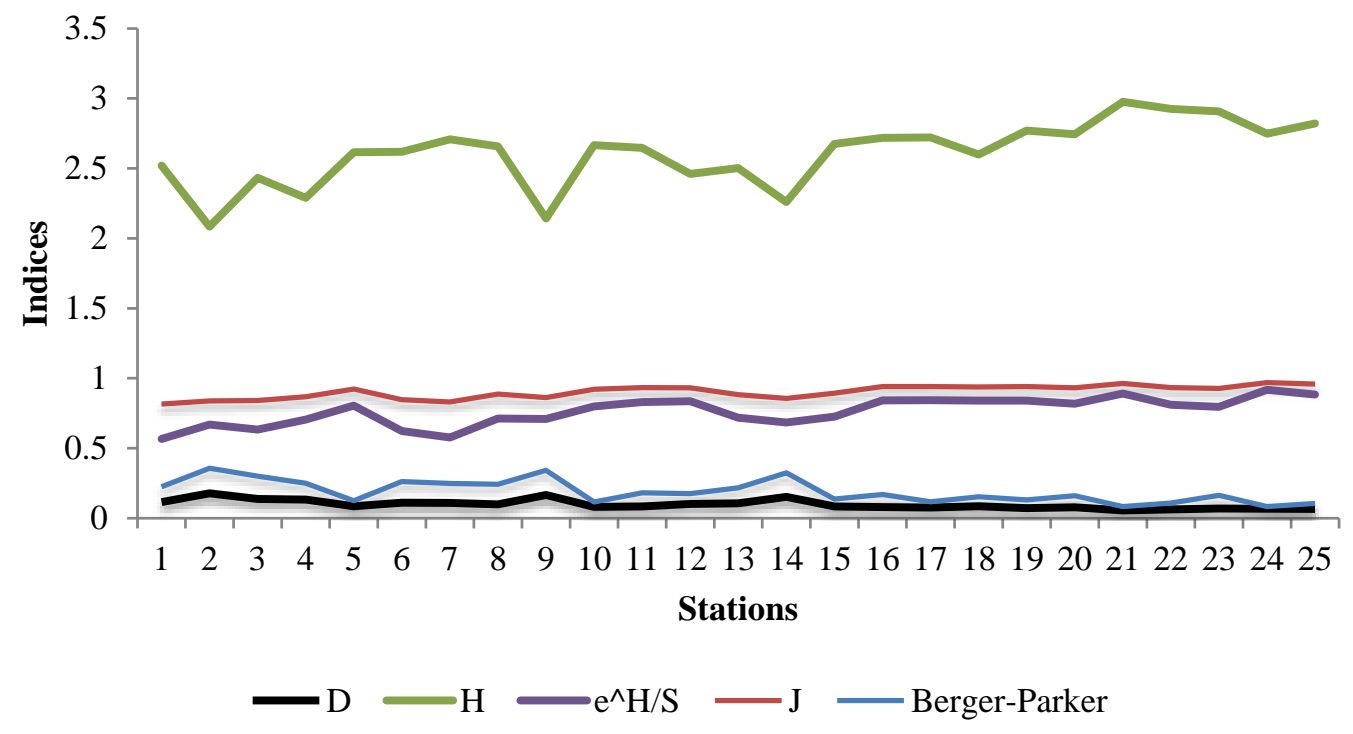

Figure 3 Variation in diversity indices with regard to study stations (D = Simpson dominance, $\mathrm{H}=\mathrm{Shannon}-\mathrm{Weaver}$ index, $\mathrm{e}^{\wedge} \mathrm{H} / \mathrm{S}=$ index of Hill, $\mathrm{J}=$ regularity of Pielou).

\subsection{Approximation of study stations according to floristic similarities}

Results based on correspondence factor analysis show 3 groups of stations defined by species that are common to them (Fig. 4). The F1 and F2 axis (20.71\% of inertia) are positively correlated to the group I consisting of stations 16 , 21 and 25 by the exclusive species such as Cyclotella ocellata, Cymbella gamma, Gomphosphaeria natans, Gyrodinium rubricaudatum, Melosira varians, Merismopedia elegans, Navicula cryptocephala, Oscillatoria boryana, Peridinium sp., Phacus longicauda, Pleurotaenium ehrenbergii, Stigeoclonium sp. and Tabellaria flocculosa. Group II is positively and 
negatively correlated to F1 and F2 respectively. It includes stations 18, 22, 23 and 24 from the species that are exclusive to them. These are: Aphanizomenon flosaquae, Aphanocapsa holsatica, Astasia torta, Diatoma mesodon, Diatomella sp., Euglena mutabilis, Gomphonema parvulum, Nostoc palludosum, Pinnularia gibba, Pyramimonas sp., Spirulina subsalsa, Staurastrum aculeatum, Synechocystis aquatilis, Tabellaria fenestrata, Thalassiosira pseudonana, Ulothrix zonata and Xanthidium sp. Group III consists of the species common to all the stations: Actinastrum sp., Anabaenopsis sp., Ankistrodesmus gracilis, Ankistrodesmus sp., Aphanocapsa litoralis, Aulacoseira crenulata, Aulacoseira sp., Caloneis bacillum, Chlamydomonas sp., Closterium acerosum, Closterium sp., Coscinodiscus amplus, Coscinodiscus angstii, Coscinodiscus sp., Cosmarium margaritatum, Cryptomonas ovata, Cryptomonas sp., Cyclostephanos sp., Cyclotella gamma, Cyclotella stelligera, Cymbella gadjiana, Cymbella kappii, Cymbella naviculiformis, Cymbella sp., Cymbella ventricosa, Diatoma sigma, Diatoma sp., Diatoma tenuis, Diatomella balfouriana, Diploneis elliptica, Epithemia adnata, Euglena spirogyra, Euglena viridis, Fragilaria capucina, Fragilaria mormonorum, Fragilariforma viriscens, Gloeodinium montanum, Gloeocystis sp., Gonatozygon monotaenium, Gyrodinium rubricaudatum, Lepocynclis sp., Merismopedia sp., Microcoleus lacustris, Mougeotia sp., Navicula Cryptotenelloides, Navicula gregaria, Navicula lenzii, Navicula nivalis, Navicula sp., Nitzschia fonticola, Nitzschia sigma, Nodularia sp., Nostoc endophytum, Oedogonium acuminatum, Oedogonium alternans, Oscillatoria chalibae, Oscillatoria granulosa, Pediastrum duplex, Peridinium pusillum, Phacus orbicularis, Phacus sp., Phacus onyx, Pinnularia sp., Planothidium lanceolatum, Pseudostaurosira brevistriata, Raphidiopsis curvata, Raphidiopsis mediterranae, Raphidiopsis sp., Rhodomonas sp., Rivularia aquatica, Rivularia sp., Spirogyra sp., Spirulina subtillissima, Spirulina tenuis, Skeletonema costatum, Staurastrum acerosum, Stephanodiscus alpinus, Stephanodiscus hantzschuii, Stephanodiscus sp., Synochocystis aquatilis, Chloromonas granulata, Trachelomonas hispida, Trachelomonas sp., Uronema elongatum and Zygnema stellinum.

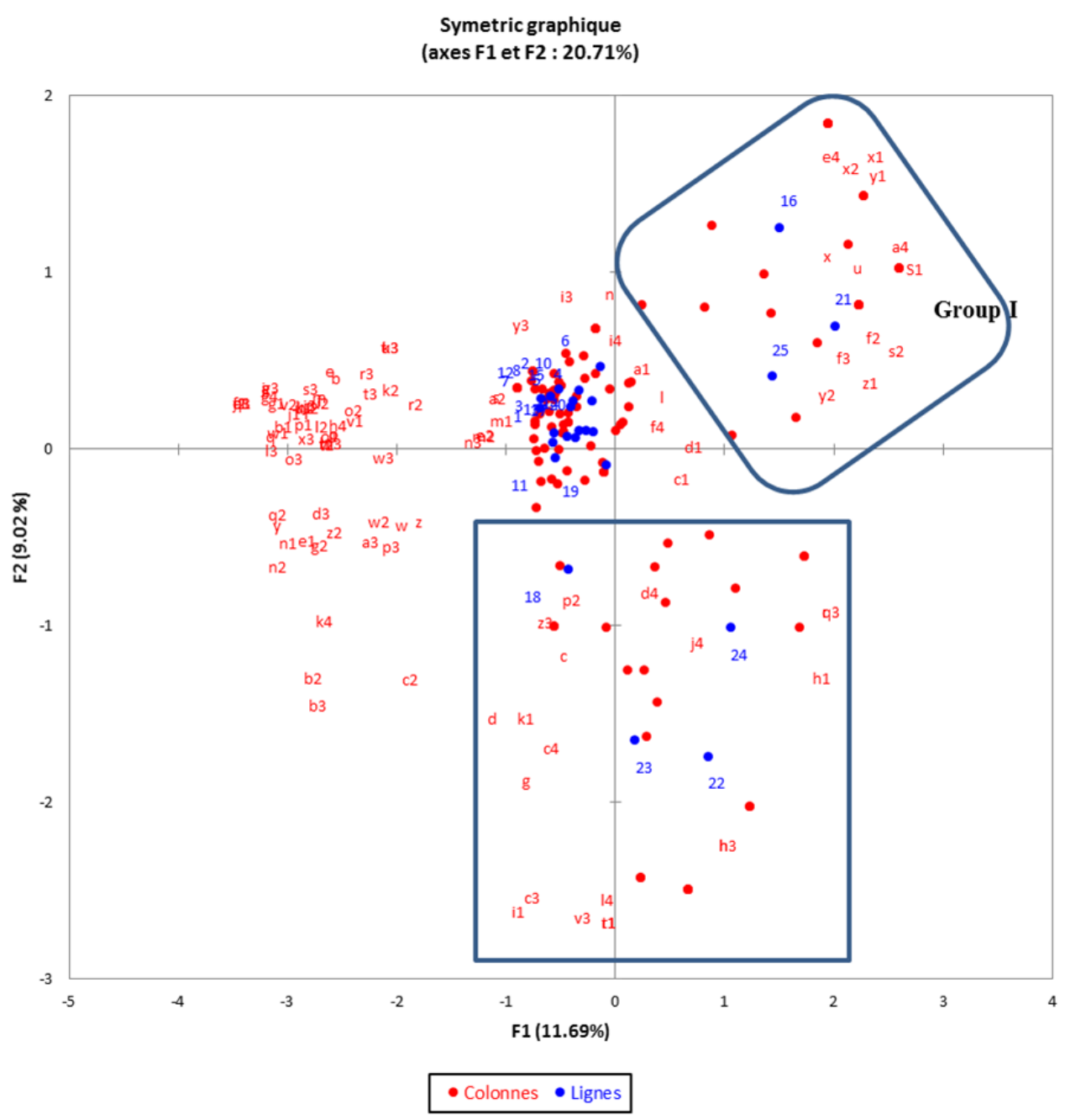

Figure 4 Approximation of the study stations according to the micro-algae species according to the F1 $\times$ F2 factorial designs of the correspondence factor analysis 
Actinastrum hantzschii Lagerheim, G. = a, Anabaenopsis sp. = b, Ankistrodesmus gracilis (Reinsch) Korshikov = c, Ankistrodesmus sp. = d, Aphanizomenon flosaquae Ralfs ex Bornet, E \& Flahault, $\mathrm{C}=$ e, Aphanocapsa holsatica (Lemmermann) G. Cronberg \& Komarek = f, Aphanocapsa litoralis Hansgirg = g, Astasia limpida Dujardin = h, Aulacoseira crenulata (Ehrenberg) Thwaites $=\mathrm{i}$, Aulacoseira sp. = j, Caloneis bacillum (Grunow) Cleve $=\mathrm{k}$, Chlamydomonas sp. = l, Closterium acerosum (Ehrenberg) Ralfs $=\mathrm{m}$, Closterium $\mathrm{sp} .=\mathrm{n}$, Coscinodiscus amplus Ehrenberg $=0$, Coscinodiscus angstii Gran = p, Coscinodiscus sp. = q, Cosmarium margaritatum (P. Lundell) J. Roy \& Bisset = r, Cryptomonas ovata Ehrenberg = s, Cryptomonas sp. = t, Cyclostephanos $\mathrm{sp} .=\mathrm{u}$, Cyclotella gamma Sovereign $=\mathrm{v}$, Cyclotella ocellata Pantocsek $=\mathrm{w}$, Cyclotella stelligera (Cleve \& Grunow) Van Heurck = $\mathrm{x}$, Cymatopleura solae (Brébisson) W. Smith = y, Cymbella gadjiana Maillard = z1, Cymbella kappii (Chlonoky) Chlonoky = a1, Cymbella naviculiformis Auerswald ex Heiberg = b1, Cymbella sp. = c1, Cymbella ventricosa Kützing = d1, Diatoma mesodon (Ehrenberg) Kützing = e1, Diatoma signata Dujardin = f1, Diatoma sp. = g1, Diatoma tenuis C. Agardh = h1, Diatomella balfouriana Greville = i1, Diatomella sp. = j1, Diploneis elliptica (Kützing) Cleve = k1, Epithemia adnata (Kützing) Brébisson = 11, Euglena mutabilis F. Schitz = m1, Euglena spirogyra Ehrenberg = n1, Euglena viridis (OFMüller) Ehrenberg $=01$, Fragilaria capucina Desmazières $=\mathrm{p} 1$, Fragilaria mormonorum $($ Grunow) CSBoyer $=\mathrm{q} 1$, Fragilariforma viriscens (Ralfs) DMWilliams \& Round = r1, Gloeodinium montanum GAKlebs = s1, Gloeocystis sp. = t1, Gomphonema parvulum (Kützing) Kützing = u1, Gomphosphaeria natans Komarek \& Hindak = v1, Gonatozygon monotaenium De Bary = w1, Gyrodinium rubricaudatum Kofoid \& Swezy = x1, Lepocynclis sp. = y1, Lyngbya martensiana Meneghini ex Gomont = z1, Melosira varians C. Agardh = a2, Merismopedia elegans A. Braun ex Kützing = b2, Merismopedia sp. = c2, Microcoleus lacustris Farlow ex Gomont = d2, Mougeotia sp. = e2, Navicula cryptocephala Kützing = f2, Navicula cryptotenelloides Lange-Bertalot = g2, Navicula gregaria Donkin = h2, Navicula lenzii Hstedt = i2, Navicula nivalis Ehrenberg = j2, Navicula sp. = k2, Nitzschia fonticola (Grunow) Grunow = 12, Nitzschia sigma (Kützing) W. Smith $=\mathrm{m} 2$, Nodularia sp. $=$ o2, Nostoc endophytum Bornet \& Flahault $=$ p2, Nostoc palludosum Kützing ex Bornet \& Flahaut = q2, Oedogonium acuminatum (Hirn) Tiffany = r2, Oedogonium alternans Wittrock \& P. Lundell ex Hirn = s2, Oscillatoria boryana Bory ex Gomont $=\mathrm{t} 2$, Oscillatoria chalibae Mertens ex Gomont $=\mathrm{u} 2$, Oscillatoria granulosa Corda $=$ v2, Pediastrum duplex Meyen = w2, Peridinium pusillum (Pénard) Lemmermann = x2, Peridinium sp. $=\mathrm{y} 2$, Phacus longicauda (Ehrenberg) Dujard = z2, Phacus orbicularis K. Hübner = a3, Phacus sp. = b3, Phacus onyx Pochmann = c3, Pinnularia gibba (Ehrenberg) Ehrenberg = d3, Pinnularia sp. = e3, Planothidium lanceolatum (Brébisson ex Kützing) Lange-Berqtalot $=\mathrm{f} 3$, Pleurotaenium ehrenbergii (Ralfs) De Bary $=\mathrm{g} 3$, Pseudostaurosira brevistriata Grunow $=$ h3, Pyramimonas sp. = i3, Raphidiopsis curvata FEFritsch \& MFRich = j3, Raphidiopsis mediterranae Skuja = $\mathrm{k} 3$, Raphidiopsis sp. = 13, Rhodomonas sp. = m3, Rivularia aquatica De Wildeman = n3, Rivularia sp. = o3, Spirogyra sp.1 = p3, Spirulina subsalsa Oersted ex Gomont = q3, Spirulina subtillissima Kützing ex Gomont = r3, Spirulina tenuis (Brühl \& Biswas) Geitler = s3, Skeletonema costatum (Greville) Cleve = t3, Staurastrum acerosum M. Schmidt $=\mathrm{u} 3$, Staurastrum aculeatum Meneghini ex Ralfs = v3, Stephanodiscus sp. = w3, Stephanodiscus alpinus Hustedt = x3, Stephanodiscus hantzschuii Grunow = y3, Stigeoclonium aestivale (Hazen) Collins = z3, Stigeoclonium sp. = a4, Synochocystis aquatilis Sauvageau = b4, Tabellaria fenestrata (Lyngbye) Kützing = c4, Tabellaria flocculosa (Roth) Kützing = d4, Chloromonas granulata (Peterfi) Gerloff \& Ettl = e4, Thalassiosira pseudonana Halse \& Heimdal = f4, Trachelomonas hispida (Perty) F. Etape = g4, Trachelomonas sp. = h4, Ulothrix zonata $(\mathrm{F}$. Weber \& Mohr) Kützing = i4, Uronema elongatum Hodgetts = j4, Xanthidium sp. = k4, Zygnema stellinum (OF Müller) C. Agardh = 14 .

\subsection{Density variation of study stations}

The total micro-algal density was $40.15 \times 10^{6} \pm 10.10 \times 10^{6}$ ind/L and varied from $24 \times 10^{5} \pm 2.17 \times 10^{5}$ ind/L at station 1 to $8 \times 10^{5} \pm 3.76 \times 10^{5}$ ind/L at station 9 (Fig. 5). It varies between the different classes and study stations, from a maximum value for Cyanophyceae for stations 6 and $15 \times 10^{5} \pm 2.72 \times 10^{5}$ ind/L, followed for station 17 of $10.5 \times 10^{5} \pm$ $4.44 \times 10^{5}$ ind/L. 


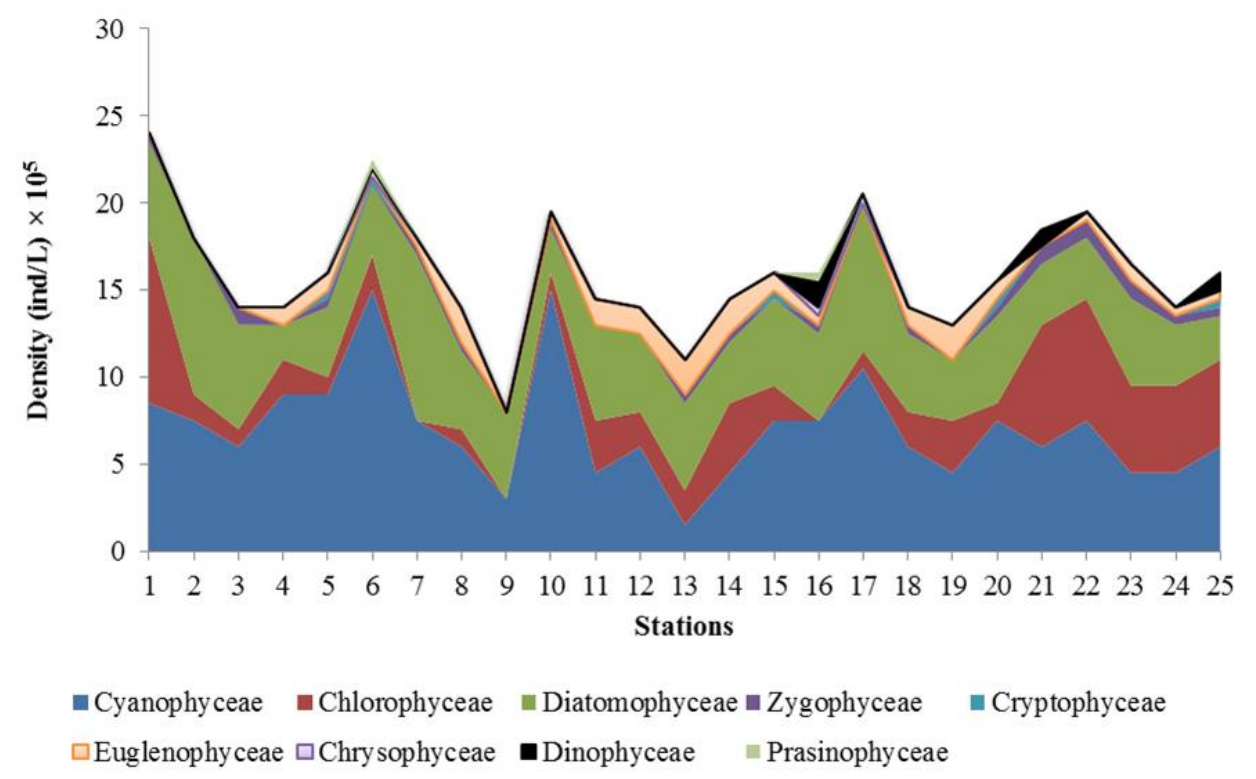

Figure 5 Variation of the dominant microalgal densities in the stations.

\subsection{Geographical distribution of abundant microalgae with a frequency greater than $25 \%$ of samples}

The cartographic analysis of variation of microalgae class densities in each station highlights a subdivision into two areas (Fig. 6). Area 1 is very marked by the dominance of 3 classes of microalgae: Cyanophyceae, Chlorophyceae and Bacillariophyceae. Area 2 is characterized by the dominance of 2 classes of microalgae namely Cyanophyceae and Bacillariophyceae. In this area the class of Chlorophyceae appears with low density.

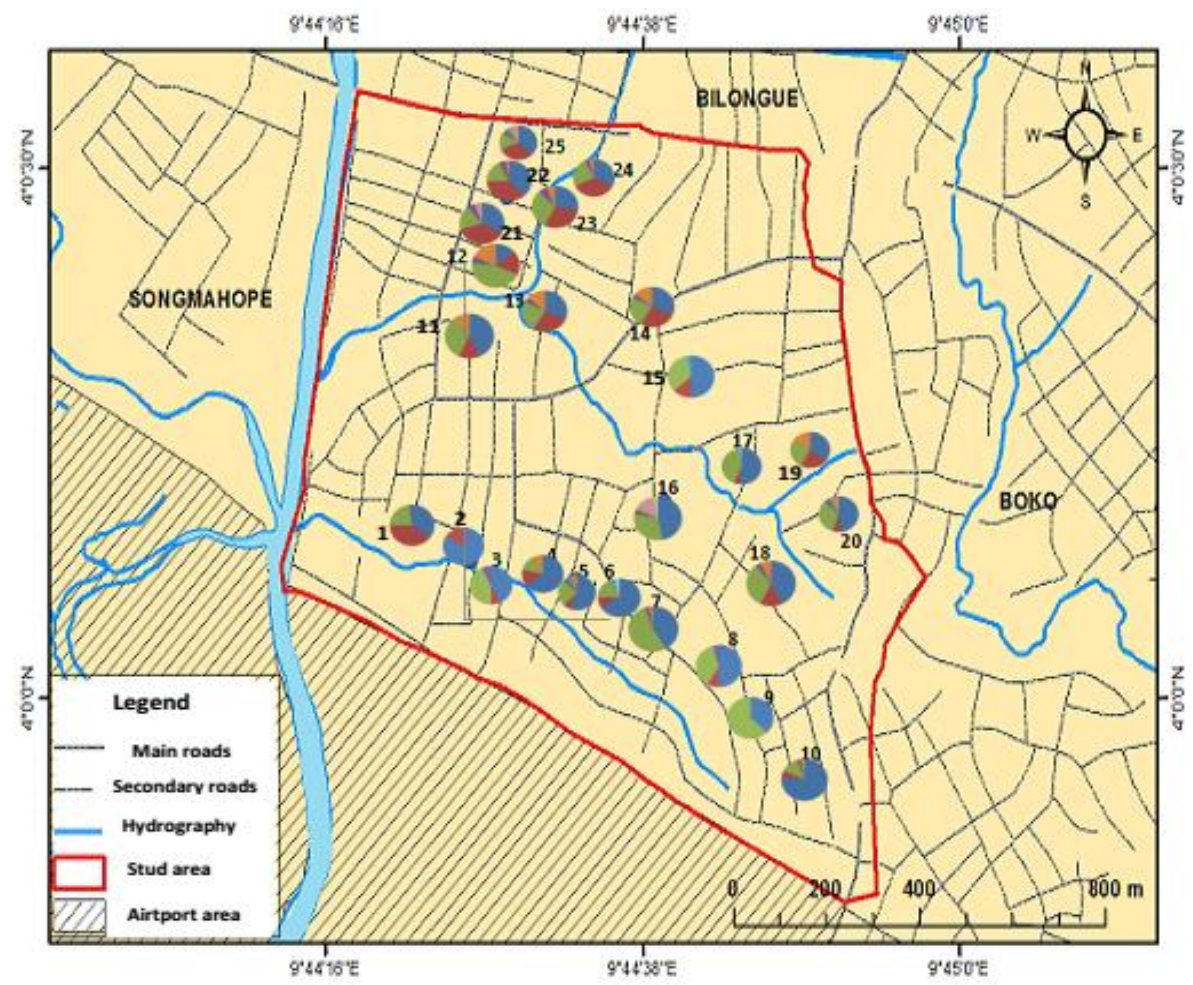

Figure 6 Spatial representation of the sectoral diagrams of different classes of microalgae according to the stations. 


\section{Discussion}

The results of the species richness amounting to 116 species show a significant wealth in the sampling stations. These results are consistent with those of Dibong and Ndjouondo [23] who inventoried the algal microflora of rivers covering the Kambo and Longmayagui sub-watersheds. These authors obtained 105 species in these study sites. This similarity in results can be attributed to the fact that the sampling sites are exposed to same sources of pollution. In addition, these authors showed that the high temperatures which occur throughout the year select for development of microalgae and consequently for high species richness. According to Jourdan [24], temperature is an important factor in development of algae which develop optimally at temperatures close to $37^{\circ} \mathrm{C}$ [25].

The most represented class was Bacillariophyceae with 33 species. According to OFEV [19], Diatoms are the most represented and dominant class in stream sampling. This would be due to their size and their ability to detach themselves from the supports to find themselves drifting in the current $[19,23,26]$. These results corroborate those of Dibong and Ndjouondo [23] who sampled microalgae of Kambo and Longmayagui rivers. These results are also in line with those of some authors who focused on phytoplankton from the Tongo'o Bassa River [13], and Miana and Tongo'o Bassa rivers in Douala [27]. Furthermore, our findings agreed with those of Ndjouondo et al. [14] who sampled the periphyton of the Batika and Tongo'o Bassa rivers. Conversely, our findings are not consistent with results of Millo [28] who reported Chlorophyceae was the most represented class in Batika river in Douala. This could be explained by the more rapid water flow in this river from upstream to downstream compare to those abovementioned. Higher water flows are known jeopardize the multiplication of diatoms [14]. Besides, this difference between results could also attribute to discrepancies related to quality of water. Indeed, Batika river is located in weakly anthropized forest area and thus less at risk of pollution of human origin. Leaching of soils due to precipitations are the only sources of pollution in this area.

The genera Navicula and Cymbella were reported as the most important in terms of abundance in our study. These findings are consistent with those found by Dibong and Ndjouondo [23] in Kambo and Longmayagui rivers in Douala. These authors showed that these both genera were abundant in waters polluted with organic matter. Besides, the number of species was highest at Station 7 because of the moderate pollution and the regular mixing of water by hens and ducks that easily access the deposited waste.

The diversity indices through different study stations varied in a "sawtooth" way. However, the most important values appear mainly between the stations 21 to 25. These results are not in line with those of Fokou [13], Dibong and Ndjouondo [23], Millo [28], and Kouefout [27] which showed that the specific richness increases from upstream to downstream in the same study rivers. However, the study stations are pollution points and vary according to the degree of pollution. Waters are stagnant at stations 21 to 25 owing to their obstruction by deposits of polyethylene bottles that promote the sedimentation of solid particles therefore contributing to the installation of the land. Dibong and Ndjouondo [11] found similar results and indicated that these canals are poorly maintained. As a result, this contributes to the proliferation of macrophytes and then facilitates the sedimentation of particles. In addition, residents dump pigs manures on the edge of these canals. When the rains come, they leave organic sludge that is brewed by the passage of motorcycles causing large temporary pool which could allow for a strong development of algae [5, 29].

According to Ndjouondo et al. [5], the poorly controlled extension of large urban centers has led to the proliferation of densely populated neighborhoods. In most cases these neighborhoods have developed in lowland areas, usually drained by a small stream. In these so-called "at risk" areas, populations are mainly poor and their principal means for water supply are drilling or wells dug not far from latrines. These areas are hallmarked by the absence or insufficiency of roads, and discharging household solid wastes into the drains. According to Ndjouondo et al. [22], riparian wetlands are special environments at the interface between aquatic and terrestrial environments that extend across rivers. They are characterized by the presence of water on the surface or near the surface of the soil temporarily or permanently. These wetlands are the seat of various functions such as the regulation of the water regime (clipping of flood peaks, support of low water levels) or the maintenance of water quality (retention and elimination of nutrients including phosphorus and nitrogen).

The results of the correspondence factor analysis revealed the presence groups of stations which isolate themselves from others by peculiarities. These features might be related to local residents' habits because they are much more spatially and temporally marked in the study area. Indeed, stations 1 to 10 are more polluted owing to household waste compare to stations 18 to 25 which are exposed to pollution from livestock waste such as pig slurry and chicken droppings. Stations 22 to 25 are also exposed to hydrocarbons from vehicles and motorcycles garages. According to Kouefout [27], species are distributed in environments with respect to the nature of pollutants and their level of 
resistance to pollutants. The authors showed that the Nostoc and Navicula genera were resistant to organic pollution. These results are in agreement with our findings. The species Nostoc palludosum, Navicula cryptocephala Aphanizomenon flosaquae, Aphanocapsa holsatica, Astasia torta, Diatoma mesodon, Diatomella sp., Euglena mutabilis, Gomphonema parvulum, Pinnularia gibba, Pyramimonas sp., Spirulina subsalsa, Staurastrum aculeatum, Synochocystis aquatilis, Tabellaria fenestrata, Thalassiosira pseudonana, Xanthidium sp., Cyclotella ocellata, Cymbella gadjiana, Gomphosphaerium natans, Gyrodinium rubricaudatum, Melosira varians, Merismopedia elegans, Oscillatoria boryana, Phacus longicauda, Pleurotaenium ehrenbergii and Ulothrix zonata tolerate organic pollution.

Densities of microalgae were variable between stations but the Cyanophyceae class appears to be invariably the densest class in each station. These results may be due to the fact that Cyanophyceae form efflorescence in streams polluted with organic matter where the speed of the current is very slow or zero. These results are in line with those of Aurrousseau [30] who worked on the evaluation of the impact of watercourses on eutrophication in the coastal band in France, Groga [31] who focused on the structure, the functioning and the dynamics of phytoplankton in Lake Ta'abo in Côte d'Ivoire and Sana'a [10] who addressed the structure, dynamics and physico-chemical and phytoplanktonic typologies of the Bou Regreg estuary in Morocco. For these authors, the stagnant waters polluted with organic matter undergo strong eutrophication by letting appear efflorescence by the multiplication of one or a few species. Iltis [18] showed that these species are generally cyanobacteria in the intertropical region where water is warm all year.

\section{Conclusion}

The objective of the study was to determine the structure and the spatiotemporal variation of the micro-algae of some channels near the garbage dumpsites of the Bobongo sub-catchment in order to propose methods of ecological management of these risk zones. The specific richness amounts to 13 classes, 34 orders, 52 families, 69 genera and 116 species. The dominant class is that of Bacillariophyceae (33 species) with a proportion of $28.45 \%$. The ShannonWeaver Index was low and ranged between 2.08 (Station 2) and 2.97 (Station 21). The microalgal density was $40.15 \times 10^{6} \pm 10.10 \times 10^{6}$ ind/L (range: $24 \times 10^{5} \pm 2.17 \times 10^{5}-8 \times 10^{5} \pm 3.76 \times 10^{5} \mathrm{ind} / \mathrm{L}$ ). Results based on correspondence factor analysis revealed 3 groups of stations (clusters): the group I from stations 16, 21 and 25 consisted of exclusive species such as Cyclotella ocellata, Cymbella gamma, Gomphosphaeria natans, Navicula cryptocephala, and Tabellaria flocculosa. This group was exposed to hydrocarbon pollution. Group II from stations 18, 22, 23 and 24 consisted of exclusive species such as Aphanizomenon flosaquae, Aphanocapsa holsatica, Astasia limpida and Ulothrix zonata. This group was exposed to pollution by pig manure and chicken dropping. Group III was made up of species common to all stations including Anabaenopsis sp., Ankistrodesmus gracilis and Zygnema stellinum for instance. Cyclotella ocellata, Cymbella gamma, Gomphosphaerium natans, Navicula cryptocephalla and Tabellaria flocculosa are hydrocarbonpolluting species. These species could be used as indicators of pollution in the framework of environmental planning for a better follow-up of the quality of waters of this region. This study also contributes to the knowledge of algal biodiversity in Africa, in particular Cameroon. From species that are exclusive to polluted hydrocarbon waters, a real scourge in the cities of the rapidly expanding Saharan Africa, it would therefore be possible to popularize them, to determine the genetic factors at the origin of their proliferation in these risk zones in order to propose them in bioremediation.

\section{Compliance with ethical standards}

\section{Acknowledgments}

We thank Pr Ba'ana Etoudi Marie Louise for her help during sampling. She has given us material for analysis of sampled.

\section{Disclosure of conflict of interest}

There is no conflict of interest.

\section{References}

[1] Ramsar. (2013). The Ramsar Convention Manual. Ramsar, Iran, 5-6.

[2] Brunet RC and Astin KB. (2000). Role of a flood zone, selective filter for some dissolved or particulate elements from a watershed. In: Wicherek S. (Eds.), Water, from the cell to the landscape. Elsevier, Paris, 157-170. 
[3] Fustec E and Lefeuvre JC. (2000). Functions and values of wetlands. Dunod, Paris.

[4] Meva'a AD, Fouda M, Bonglam CZ and Kamwo M. (2010). Spatial Analysis of Flood Risk in the Mbanya Watershed in Douala, Economic Capital of Cameroon. Report, NOVATECH, The University of Douala, 20-27.

[5] Ndjouondo GP, Ba'ana Etoundi ML, Nwamo RD, Fankem H and Dibong SD. (2016). Impact of human activities on the wetlands of the Kambo and Longmayagui rivers (Douala). International Journal of Innovation and Scientific Research, 26(1), 410-420.

[6] Nwamo RD, Ndjouondo GP, Ba'ana Etoundi ML, Dibong DS and Tchoumbougnang F. (2017). Impacts of anthropogenic actions on the wetlands of the city of Douala and sustainable management solutions: case of the Tongo'o Bassa river. International Journal of Innovation and Scientific Research, 29(1), 10-22.

[7] Tchuikoua LB. (2010). Household solid waste management in Douala, Cameroon: Opportunity or threat to the environment? Ph.D Thesis, University of Bordeaux, France, 77-155.

[8] Tchounga GB. (2016). Local governance and natural risk management in Douala V. Master Thesis in Geography, The University of Douala, Cameroon, 145-167.

[9] Fogwe NZ and Tchotsoua M. (2007). Geographical evaluation of two decades of flood control in the city of Douala (Cameroon). Report, The University of Douala, http: //www.infotheque.info/files/JSIR-AUF-Hanoi07, last accessed on 27/12/2019.

[10] Sana'a B. (2006). Structure, dynamics and physicochemical and phytoplanktonic typologies of the Bou Regreg estuary (Moroccan Atlantic coast). Ph.D. thesis, Mohammed V University-Agdal, Faculty of Science, 76-80.

[11] Dibong SD and Ndjouondo GP. (2014). Floristic inventory and ecology of aquatic macrophytes of the Kambo River in Douala (Cameroon). Journal of Applied Biosciences, 80, 7147-7160.

[12] Priso RJ, Dibong SD, Tchinda-Metagne C, Taffouo VD, Din N and Amougou A. (2010). Impacts of polluted waters on growth, chlorophyll contents and organic substances in the leaves of two Poaceae. International Journal of Biological and Chemical Sciences, 4(4), 1122-1129.

[13] Fokou TG. (2015). Floristic inventory and ecology of aquatic macrophytes and microalgae of the Tongo'o Bassa River in Douala. Master Thesis, The University of Douala, 30-60.

[14] Ndjouondo GP, Ba'ana Etoundi ML, Nwamo RD, Fankem H and Dibong SD. (2017). Comparative analysis of the water quality of the Kambo and Longmayagui rivers (Douala) from diatom biological indices. International Journal of Innovation and Scientific Research, 33(1), 45-55.

[15] Bourrelly P. (1966). Freshwater algae: green algae. N. Boubee \& Cie, Paris, 61-65.

[16] Bourrelly P. (1968). Freshwater algae: yellow and brown algae. N. Boubee \& Cie, Paris, 50-55.

[17] Bourrelly P. (1970). Freshwater algae: blue and red algae. N. Boubee and Cie, Paris, 66-70.

[18] Iltis A. (1980). Algae. In: Durand JR. and Leveque C. (Eds.), Flora and Aquatic Fauna of Sahelo-Sudanian Africa. ORSTOM, Paris, 9-61.

[19] OFEV. (2007). Methods of Analysis and Assessment of Watercourses, Diatom level R (Region). FOEN, Berne.

[20] Frey W. (2015). Syllabus of Plant Families Adolf Engler's Syllabus der Pflanzenfamilien. Photoautotrophic eukaryotic Algae Glaucocystophyta, Cryptophyta, Dinophyta/Dinozoa, Haptophyta, Heterokontophyta/Ochrophyta, Chlorarachniophyta/Cercozoa, Euglenophytal Euglenozoa, Chlorophyta, Streptophyta. Borntraeger Science Publishers, Stuttgart, 13th. Ed., Part 2/1, 50-55.

[21] Guiry MD and Guiry GM. (2019). AlgaeBase. World-wide electronic publication, National University of Ireland, Galway, http://www.algaebase.org., last accessed on 27/12/2019.

[22] Ndjouondo GP, Ba'ana Etoundi ML, Nwamo RD, Fankem H and Dibong SD. (2017). Ecology of Uronema elongatum of some rivers of Littoral Region, Cameroon. International Journal of Innovation and Scientific Research, 33(1), 24-39.

[23] Dibong, SD and Ndjouondo GP. (2014). Floristic inventory and ecology of algae Kambo and Longmayagui rivers of the Douala wetland (Cameroon). International Journal of Biological and Chemical Sciences, 8(6), 2560-2577.

[24] Jourdan JP. (2006). Cultivating your Spirulina: Handicraft Manual for Spirulina Production, http://www.spirulinasource.com/microjourdan.html, last accessed on 05/10/2019. 
[25] Cruchot H. (2008). Spirulina, review and prospects. Thesis, University of Franche Comte, Faculty of Medicine and Pharmacy Besancon, Besancon, 176-188.

[26] Ouattara A. (2000). First systematic and ecological data of the phytoplankton of Lake Ayame (Ivory Coast). Thesis of the Catholic University Leuven, Belgium, 76-80.

[27] Kouefout Y. (2016). Analysis of the water quality of rivers and Tongo'o Bassa from physicochemistry and phytoplankton. Master Thesis, Institute of Fishery Sciences at Yabassi, The University of Douala, Cameroon, 2045

[28] Millo N. (2015). Inventory and Phytoplankton Diversity of the Batika River (Yabassi). Master Thesis, Institute of Fishery Sciences at Yabassi, The University of Douala, Cameroon, 25-36.

[29] Finkel ZV, Katz ME, Wright JD, Schofield OME and Falkowski PG. (2005). Climatically Driven Macroevolutionary Patterns in the Size of Marine Diatoms Over the Cenozoic. Proceedings of National Academy of Science, 102, 8927- 8932 .

[30] Aurousseau P. (2013). Evaluation of the impact of rivers on eutrophication in the coastal strip: need to reason about concentrations and fluxes. Biotechnology and Agronomy Societies Environnement, 17(1), 271-276.

[31] Groga N. (2012). Structure, functioning and dynamics of phytoplankton in Lake Ta'abo (Ivory Coast). PhD Thesis, University of Toulouse, France, 160-200.

\section{How to cite this article}

Ndjouondo GP, Mekoulou NJ, Kojom LP, Taffouo VD and Dibong SD. (2020). Microalgal structure and diversity in some canals near garbage dumps of Bobongo basin in the city of Douala, Cameroun. GSC Biological and Pharmaceutical Sciences, 10(2), 48-61. 